\title{
A plant DNA-binding protein increases the number of active preinitiation complexes in a human in vitro transcription system
}

\author{
Fumiaki Katagiri, ${ }^{1}$ Ken-ichi Yamazaki, ${ }^{1,4}$ Masami Horikoshi, ${ }^{2}$ Robert G. Roeder, ${ }^{2}$ and \\ Nam-Hai Chua ${ }^{1,3}$ \\ ${ }^{1}$ Laboratory of Plant Molecular Biology and ${ }^{2}$ Laboratory of Biochemistry and Molecular Biology, The Rockefeller University, \\ New York, New York 10021-6399 USA
}

TGA1a is a tobacco DNA-binding protein that binds to the activation sequence-1 (as-1) element of the cauliflower mosaic virus 35S promoter. We have produced TGA1a in Escherichia coli, purified it from bacterial extracts, and examined its effect on transcription in a human in vitro system. Addition of TGAla stimulates transcription by up to 20 times, and the stimulation is dependent on the presence of the as-1 element in the promoter. When transcription reinitiation is inhibited by $0.3 \mathrm{M} \mathrm{KCl}$, activation is similar. Therefore, TGA1a activates transcription by increasing the number of active preinitiation complexes. After formation of the preinitiation complexes in the presence of TGA1a, oligonucleotides containing TGA1a-binding sites do not significantly affect the stimulated level of transcription. This result indicates that a complex remains committed to the promoter site after initiation and that this complex is used repeatedly during several initiation events. Our study demonstrates for the first time that a plant factor can activate transcription in a human in vitro system and that the activation mechanism of the plant factor is similar to that of mammalian factors.

[Key Words: as-1; ASF-1; RNA polymerase II transcription; TGAla; transcription activation mechanism]

Received July 3, 1990; revised version accepted August 21, 1990.

It has been suggested that unrelated eukaryotes may share a common mechanism for transcription activation (Ptashne 1988). For example, a yeast transcription activator, GAL4, has been shown to function in mammalian (Kakidani and Ptashne 1988; Webster et al. 1988), insect (Fisher et al. 1988), and plant cells (Ma et al. 1988). Examples of such transcriptional compatibility among unrelated eukaryotes are, however, still limited; in particular, there has been no report concerning the activity of a plant transcription factor in other organisms.

The $35 \mathrm{~S}$ promoter of cauliflower mosaic virus (CaMV) is responsible for the transcription of the entire virus genome; the transcript (35S RNA) is used as the template for virus replication through reverse transcription (Guilley et al. 1982; Pfeiffer and Hohn 1983). This promoter shows strong and apparently constitutive expression in several plants in the absence of any viral products (Odell et al. 1985; Sanders et al. 1987). Analyses of $35 \mathrm{~S}$ promoter mutants in transgenic tobacco have shown that the constitutive expression of the pro-

${ }^{3}$ Corresponding author.

"Present address: Research Institute for Biochemical Regulation, School of Agriculture, Nagoya University, Chikusa, Nagoya 464-01, Japan. moter results from the combinatorial properties of different domains in the upstream region, each of which confers a different expression pattern on the promoter (Benfey et al. 1989, 1990a,b). Activation sequence-1 (as-1) is a cis-regulatory element in the -83 to -63 region of the $35 \mathrm{~S}$ promoter. as -1 contains a tandem repeat of a TGACG motif and confers on a heterologous promoter preferential expression in roots (Lam et al. 1989). We have characterized a tobacco nuclear factor ASF-1 that specifically binds to $a s-1$. Analysis of the binding specificity of ASF-1 to the wild-type and mutant forms of $a s-1$ suggests that this factor is involved in the in vivo function of as-1 (Lam et al. 1989). We have observed that ASF-1 also shows specific binding to other cis-regulatory elements containing the TGACG or related motifs, such as the hex-1 element $(-180$ to -160$)$ of the wheat histone H3 promoter (Mikami et al. 1987, 1989a,b; Katagiri et al. 1989), the nos-1 element $(-131$ to -111$)$ of the nopaline synthase promoter (An et al. 1986; Katagiri et al. 1989; Lam et al. 1990), and the ocs element (- 193 to -173 ) of the octopine synthase promoter (Ellis et al. 1987; Bouchez et al. 1989; Fromm et al. 1989; Singh et al. 1989 .

TGAla is a tobacco DNA-binding protein encoded by 
cDNA clones obtained from screening a cDNA expression library with a probe containing the TGACG motif (Katagiri et al. 1989). On the basis of its binding specificities to different TGACG-containing cis-elements, TGAla was suggested by us to be a good candidate for ASF-1. The high level of TGAla mRNA in roots is consistent with the notion that this DNA-binding protein is involved in the in vivo function of $a s-1$ that confers preferential expression in root (Katagiri et al. 1989). Because $a s-1$ is a positive cis-regulatory element, TGAla should be a transcription activator. Recently, we demonstrated that TGAla functions as an activator in a wheat germ in vitro transcription system (Yamazaki et al. 1990).

Compared with in vivo assay systems, the analysis of a transcription activator using a well-characterized in vitro system allows the investigation of the activation mechanisms at the molecular level (Sawadogo and Roeder 1985a; Abmayr et al. 1988; Hai et al. 1988; Horikoshi et al. 1988a,b; Workman et al. 1988, 1990; KleinHitpass et al. 1990). Among the various RNA polymerase II in vitro transcription systems, the one based on HeLa cell nuclear extracts is the best characterized (Dignam et al. 1983a,b). In this system, general transcription factors, TFIIB, TFIID, and TFIIE/F, are necessary for transcription initiation in addition to RNA polymerase II (for review, see Saltzman and Weinmann 1989).

We have investigated the function of the plant DNAbinding protein, TGAla, in a HeLa cell in vitro transcription system reconstituted with partially purified fractions of the TFIIB, TFID, TFIIE/F, and RNA polymerase II. Our results show that TGAla can function as a transcription activator in the human in vitro transcription system and that it facilitates the formation of active preinitiation complexes.

\section{Results}

\section{Overproduction of TGA1a in Escherichia coli}

TGAla was overproduced in Escherichia coli by the T7 expression system (Rosenberg et al. 1987). The coding region of TGAla was cloned downstream of the T7 promoter in the expression vector pET3a (Rosenberg et al. 1987) to obtain pKT7T1A. The plasmid pKT7T1A was designed to express the full-length TGAla protein by utilizing a Shine-Dalgarno sequence in pET3a. Sequence analysis of TGAla genomic clones revealed that the published coding region of TGAla (Katagiri et al. 1989) was short by 2 bases in the 5' region (H. Fromm, unpubl.). Therefore, we reconstructed the missing two nucleotides, AT (first two nucleotides of the methionine codon ATG), as described in Materials and methods. The coding region of TGAla is 1119 bp long, encoding 373 amino acid residues. The expression of TGAla can be induced by the addition of IPTG in the medium. Figure 1a shows the total protein profile of the bacteria before and after IPTG induction (lanes 1 and 2). After the induction, the amount of TGAla (band I) constitutes $\sim 3 \%$ of the total protein. The induced cells were used as the starting material for the purification of TGAla.

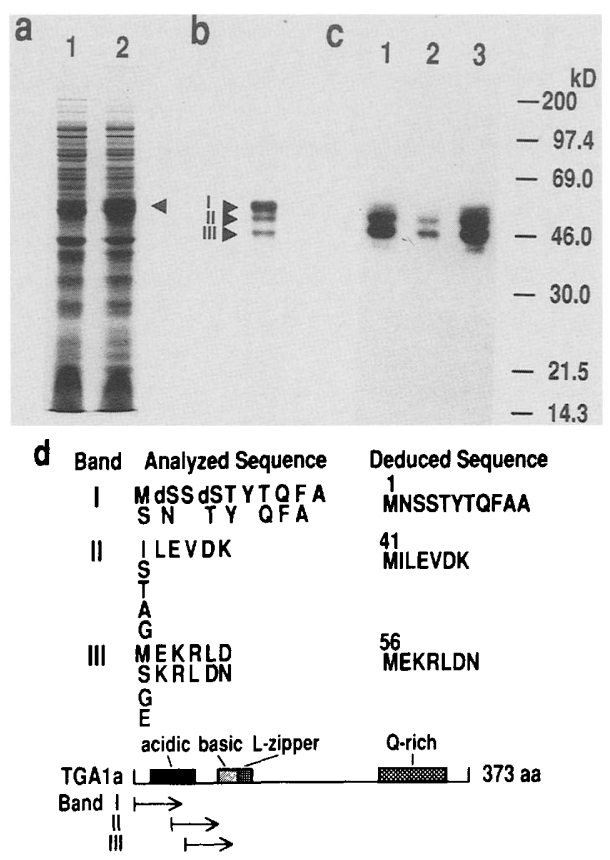

Figure 1. Overproduction and purification of TGAla. (a) Total protein profiles of $E$. coli-expressing TGAla. Total bacteria proteins $(40 \mu \mathrm{g} / \mathrm{lane})$ were separated by $10 \%$ SDS-PAGE, and the gel was stained with Coomassie Brilliant Blue. (Lane 1) Before induction; (lane 2) after induction. In lane 2, the arrowhead indicates the polypeptide that increased in concentration after induction. (b) Purified TGAla. A total of $10 \mu \mathrm{g}$ of the purified TGAla was analyzed by $10 \%$ SDS-PAGE, and the gel was stained with Coomassie Brilliant Blue. The three bands are marked as bands I, II, and III in order of decreasing molecular weight. (c) Southwestern blot analysis of purified TGAla. The purified TGAla fraction (10 $\mu \mathrm{g} / \mathrm{lane})$ was separated by $10 \%$ SDS-PAGE, and the proteins were blotted onto a nitrocellulose membrane that was probed with a labeled hex-1 sequence. (Lane 1) No competitor; (lane 2) HW added as a competitor; (lane 3) HM added as a competitor. The positions of the polypeptide bands in $a, b$, and $c$ are directly comparable. Migration positions of molecular weight markers are indicated on the right. (d) Amino-terminal sequences of bands I, II, and III. Amino-terminal sequences of bands I, II, and III (analyzed) are compared to the corresponding amino acid sequences deduced from the DNA sequence of TGAla cDNA clone (deduced) (Katagiri et al. 1989). Comparison of the sequence of band I and the deduced sequence suggests that this band likely contains a mixture of the full-length TGAla and the same polypeptide but without the first methionine. The sequence of band II suggests that it contains a truncated TGAla polypeptide with its amino terminus at position 42 . The sequence of band III suggests that it contains a mixture of two truncated TGAla polypeptides with amino termini at positions 56 and 57 . The schematic diagram at the bottom shows the relative positions of the translation start sites of the three bands in the TGAla protein. The acidic region, the basic region, the leucine (L)-zipper region, and the glutamine (Q)-rich region are shown. The amino acid sequences are shown in single-letter code. (dS) Dehydroserine. Amino acids detected in the same sequencing cycles are aligned perpendicularly. However, the first amino acids of the analyzed sequences are not trustworthy, because the first sequencing cycle is often contaminated by irrelevant amino acids. The numbers indicated over the methionine codons of the deduced sequences represent the positions of the methionine codons with respect to the first methionine. 


\section{Purification of TGA1a}

TGAla was purified as described in Materials and methods. Table 1 shows each step of the purification procedure. We obtained $1.7 \mathrm{mg}$ of TGA1a from a 2-liter bacterial culture at $>95 \%$ purity as assessed by SDSPAGE (Fig. 1b).

The purified TGAla fraction contained three molecular species when analyzed by SDS-PAGE (Fig. 1b). Amino-terminal sequence analyses of these polypeptides suggested that the three bands correspond to the products of the TGAla gene with three different amino termini in the same reading frame (Fig. 1d). Bands I, II, and III corresponded to the products that start at Met-1, Met-41, and Met-56, respectively. It is likely that Met- 41 and Met- 56 were used as cryptic translation start sites in E. coli.

The specific binding abilities of the three polypeptides were examined by Southwestern blot (Fig. 1c). All three polypeptides bound to the probe containing hex-1 of the wheat histone H3 promoter (Mikami et al. 1987), a region containing a specific binding site for ASF-1 and TGAla (Katagiri et al. 1989). It is not clear why band I gave only a weak signal, even though it was the most abundant species (see Discussion). Binding of all three polypeptides was sequence specific; the binding was competed out by the addition of an oligonucleotide containing the wild-type hex-1 (HW) but not by an oligonucleotide containing the mutant hex-1 (HM). HW bound TGAla, but HM did not (see Materials and methods). This mixture of three different polypeptides was used as the purified fraction of TGAla in subsequent experiments.

\section{Transcription activation in a human in vitro system}

The function of the purified TGAla was assayed in a human in vitro transcription system reconstituted with partially purified fractions of TFIIB, TFIID, TFIIE/F, and RNA polymerase II from HeLa cell nuclear extracts (Hai et al. 1988; Horikoshi et al. 1988b). Hereafter, we refer to these components as the HeLa general factors. The DNA templates contained two copies of either the wild-type or the mutant as-1 sequence placed upstream of the $35 \mathrm{~S}$ TATA box region (designated wild-type and mutant promoters, respectively; Fig. 2a). The mutant derivative of as-1 has a very low affinity for TGAla (Katagiri et al. 1989; Yamazaki et al. 1990). To facilitate detection of specific transcripts, a 380-bp G-free sequence (Sawadogo and Roeder 1985b/ placed 3' to the TATA box region was used as the template for RNA polymerase II.

Figure $2 \mathrm{~b}$ shows that with the wild-type promoter, addition of $50 \mathrm{ng}$ of TGAla per assay increased transcription by $\sim 10$ times (lanes 1 and 2). Addition of the same amount of TGAla gave only a small stimulation with the mutant promoter (lanes 3 and 4). This slight stimulation could result from the greatly reduced binding affinity of TGAla for the mutant as-1. Thus, our data clearly demonstrate that TGAla functions as a sequence-specific transcription activator in the HeLa in vitro transcription system.

We consistently detected a difference in the basal transcription level between the wild-type and mutant promoters (Fig. 2b, lanes 2 and 4). The reproducibility of this difference suggests that a TGAla-like activity is present in the HeLa general factors. In fact, our preparation of TFIIB and TFIID fractions showed specific binding activities to the hex-1 element when analyzed by gel retardation assays (data not shown). To deplete the binding activities, the HeLa general factors were titrated with the oligonucleotide $\mathrm{HW}$. We found that the addition of $10 \mathrm{ng}$ of $\mathrm{HW}$ per assay was sufficient to reduce the apparent high basal transcription level of the wild-type promoter (data not shown). Figure 2c shows the results obtained with the depleted HeLa general factors. With this mixture, the basal transcription level of the wild-type promoter was reduced to the same level as that of the mutant promoter (Fig. 2c, lanes 2 and 4), whereas the transcription stimulation by TGAla $150 \mathrm{ng} /$ assay) remained at a similar level (cf. lanes 1 in Fig. $2 b$ and c). In contrast to the results obtained with the untreated HeLa general factors, no transcription activation

Table 1. Purification of TGA1a

\begin{tabular}{|c|c|c|c|c|c|c|}
\hline & $\begin{array}{l}\text { Total } \\
\text { volume } \\
(\mathrm{ml})\end{array}$ & $\begin{array}{l}\text { Total } \\
\text { protein } \\
\text { (mg) }\end{array}$ & $\begin{array}{l}\text { Total } \\
\text { activity } \\
\left.\times 10^{-6} \text { (unit) }\right)^{a}\end{array}$ & $\begin{array}{l}\text { Specific } \\
\text { activity } \\
\times 10^{-5}(\mathrm{U} / \mathrm{mg})^{\mathbf{a}}\end{array}$ & $\begin{array}{l}\text { Yield } \\
(\%)\end{array}$ & $\begin{array}{l}\text { Purification } \\
\text { (-fold) }\end{array}$ \\
\hline $\begin{array}{l}\text { Crude extract } \\
\left(\mathrm{NH}_{4}\right)_{2} \mathrm{SO}_{4}\end{array}$ & 92 & 330 & 180 & 5.4 & 100 & 1 \\
\hline fraction & 4.7 & 120 & 80 & 6.5 & 44 & 1.2 \\
\hline DE-52 & 13 & 48 & 94 & 20 & 52 & 3.7 \\
\hline P11 & 4.2 & 8.0 & 59 & 73 & 33 & 14 \\
\hline $\begin{array}{l}\text { Mutant DNA } \\
\text { affinity }^{b}\end{array}$ & 21 & 3.3 & 27 & 82 & 15 & 15 \\
\hline $\begin{array}{l}\text { Wild-type DNA } \\
\text { affinity }^{b}\end{array}$ & 19 & 1.7 & 30 & 170 & 17 & 32 \\
\hline
\end{tabular}

Starting from 6 grams (wet weight) of BL21(DE3)/plysS/pKT7T1A.

${ }^{2}$ One activity unit is defined as the amount of activity that binds to $3 \%$ of the hex- 1 binding probe (1.4 fmoles) under standard assay conditions (Katagiri et al. 1989).

bOne-third of the total sample was applied to the DNA affinity columns. However, the values shown here were recalculated for the total sample. 
a
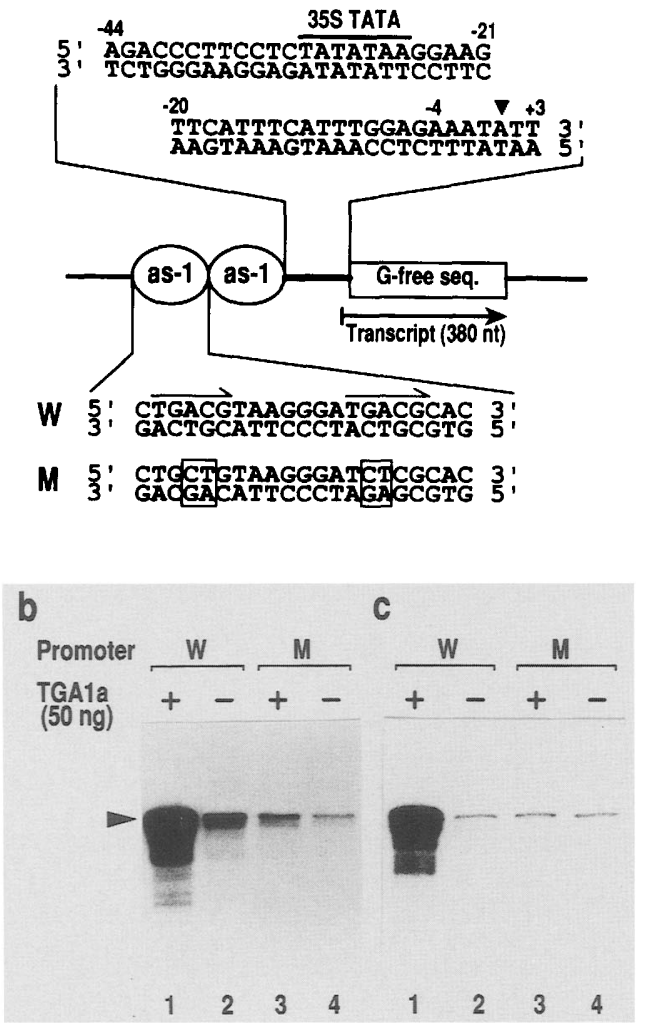

Figure 2. TGAla activates transcription in a HeLa in vitro system. $\{a\rangle$ Structures of DNA templates used for in vitro transcription. Two copies of either the wild-type (W) or mutant (M) form of as-1 were placed upstream of the 35S TATA region $(-44$ to -4$)$. The sequences of the wild-type (W) and mutant (M) forms of as-1 are shown. A tandem repeat of the TGACG motif is indicated by arrows in $W$; the mutations in $M$ are boxed. The sequence of the 35S TATA box region is also shown. The numbers indicated over the sequence represent the nucleotide positions with respect to the determined transcription initiation site (arrowhead; see Fig. 4). The 35S TATA box is overlined. G-free sequence placed downstream of the TATA region generates a 380-nucleotide-specific transcript. Details of the templates are described elsewhere (Yamazaki et al. 1990). (b) Transcription activation by TGAla using the untreated HeLa general factors. (c) Transcription activation by TGAla using the depleted HeLa general factors. (W) Wild-type promoter; (M) mutant promoter; (+) addition of TGAla (50 ng); $(-)$ no addition of TGAla. Arrowhead indicates the specific transcript of 380 nucleotides.

by TGAla was seen with the mutant promoter using the depleted HeLa general factors (cf. lanes 3 and 4 in Fig. $2 b$ and c). In subsequent experiments, the depleted HeLa general factors were used.

The transcription activation level was measured at different concentrations of TGAla (Fig. 3). With $100 \mathrm{ng}$ per assay of TGAla, we reproducibly observed 8 - to 20 fold stimulation in $>10$ independent experiments. The amounts of transcript showed an approximately linear increase with increasing amounts of TGAla. This result suggests that within the concentration range examined, TGAla does not appear to activate transcription cooperatively.
Accurate transcription initiation from the $35 \mathrm{~S}$ promoter in the HeLa cell system

Because the human in vitro transcription system is heterologous to the $35 \mathrm{~S}$ promoter, we wished to ascertain whether accurate transcription initiation is retained in this system. We found that transcription initiation from the $35 \mathrm{~S}$ promoter in the HeLa cell system (nucleotide A circled with a thick line in Fig. 4) occurred at the same site as in transgenic tobacco with respect to the position of the TATA box (Odell et al. 1985), although in the DNA template the sequence of the $35 \mathrm{~S}$ promoter downstream of -4 is different from that of the authentic $35 \mathrm{~S}$ promoter (Fig. 2a). Addition of TGAla did not alter the major transcription start site; however, a minor initiation site became apparent, which was $\sim 30$-fold weaker than the major site (Fig. 4, lane 5). Comparison of the signal strengths (Fig. 4, lanes 5 and 6) shows that TGAla increased transcription by $\sim 20$-fold. This amount of stimulation was similar to that obtained using the Gfree sequence (Fig. 3). Because there were no other significant initiation sites between -60 and +90 (only a part of this region is shown in Fig. 4), we conclude that most transcripts shorter than 380 nucleotides, which are observed in the assays using the G-free sequence (e.g., Fig. 2c, lane 1), probably result from premature transcription termination (Sawadogo and Roeder 1985a; Carcamo et al. 1989).

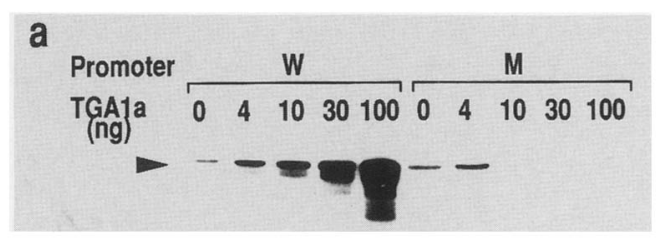

b

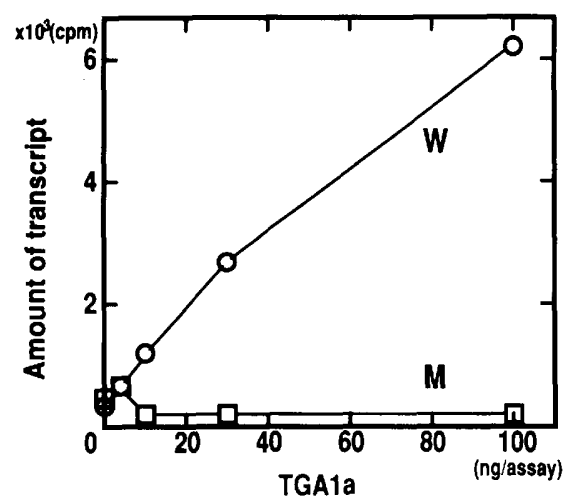

Figure 3. Effects of increasing amounts of TGAla on transcription activation. (a) An autoradiogram showing the transcripts synthesized at different concentrations of TGAla. Arrowhead indicates the position of the specific transcript. $(b)$ The gel bands corresponding to the specific transcripts were excised, and their radioactivities were determined by a scintillation counter. The amount of radioactivity was used to represent the amount of transcription. (W) Wild-type promoter; (M) mutant promoter. 


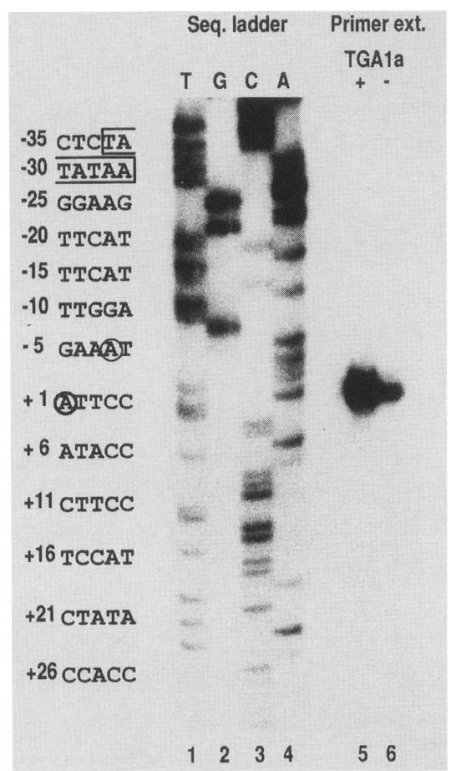

Figure 4. Transcription initiation sites of the CaMV 35S promoter in the HeLa in vitro system. Transcription initiation sites in the in vitro system were determined by primer extension. The results of transcription reactions with (100 ng/assay) or without TGAla are shown in lanes 5 and 6, respectively. A sequence ladder of the wild-type promoter obtained with the same primer used in the primer extension is shown in lanes $1-4$ as a reference. The sequence of the top strand shown in Fig. $2 \mathrm{a}$ is indicated on the left. The major and minor transcription initiation sites are circled with a thick line $(+1)$ and a thin line $(-2)$, respectively. The $35 \mathrm{~S}$ TATA sequence is boxed.

\section{TGA1 a increases the number of preinitiation complexes}

There are four possible ways that TGAla could stimulate transcription: (1) by increasing the number of active preinitiation complexes; (2) by increasing the initiation frequency from a single preinitiation complex; (3) by increasing the elongation rate; or (4) by a combination of these possibilities. We examined whether TGAla increases the number of preinitiation complexes under the condition of limited transcription reinitiation (Fig. 5). A high concentration of $\mathrm{KCl}(0.3 \mathrm{M})$ inhibits initiation but does not inhibit elongation in a HeLa cell RNA polymerase II transcription system (Cai and Luse 1987). Thus, when added just after the first round of initiations, $0.3 \mathrm{M} \mathrm{KCl}$ inhibits further initiation events, such that the number of transcripts corresponds to the number of active preinitiation complexes (i.e., one transcript is derived from one preinitiation complex). We define singleround transcription as that observed under conditions in which one initiation event from each preformed preinitiation complex is allowed and multiple-round transcription as that observed when greater than a single round of transcription initiation is allowed. Although the experimental systems are not completely the same as that in this study, previous observations with the adenovirus major late promoter in HeLa cell in vitro systems showed that the first round of initiation from preformed preinitiation complexes is completed within
0.5 min after addition of nucleoside triphosphates (Hawley and Roeder 1985) and that subsequent rounds of initiations do not occur within 5 min (Hawley and Roeder 1987). In our experiments, the concentration of $\mathrm{KCl}$ was raised from $50 \mathrm{~mm}$ (standard assay conditions) to $0.3 \mathrm{M}, 0.5 \mathrm{~min}$ after the initiation of the reaction. We assumed that this change in $\mathrm{KCl}$ concentration occurs early enough to exclude significant contributions from second rounds of initiation to the final amount of transcript.

In the analysis shown in Figure 5, preinitiation complexes were formed by preincubation of the DNA template with the HeLa general factors in the presence and absence of TGAla. The transcription reaction was then initiated by the addition of NTPs (Fig. 5a). Addition of $\mathrm{KCl}$ (final $0.3 \mathrm{M}$ ) at $0.5 \mathrm{~min}$ before the addition of NTPs (Fig. 5a, time point I) almost completely inhibited subsequent transcription initiation (Fig. 5b, lanes 1 and 2), whereas addition of the same concentration of $\mathrm{KCl}$ at 0.5 min after the addition of NTPs (Fig. 5a, time point II) did not. In this latter case, accumulation of the transcript terminated within $10 \mathrm{~min}$ (Fig. 5b, lanes $3-8$ ). The only transcript that accumulated was 380 nucleotides (Fig. 5, lanes 3,4 , and $6-8$ ). The appearance of only this fulllength transcript suggests that under our conditions the second round of transcription is indeed inhibited (Sawadogo and Roeder 1985a; Carcamo et al. 1989). We found that $0.3 \mathrm{M} \mathrm{KCl}$ appeared to affect the elongation rate slightly (Fig. 5b, cf. lanes 5 and 11). After a 5-min incubation at $0.3 \mathrm{M} \mathrm{KCl}$, the average length of the transcripts was $\sim 310$ nucleotides (Fig. 5b, lane 5). On the other hand, after a 5 -min incubation at $50 \mathrm{mM} \mathrm{KCl}$ (standard assay conditions) most of the transcripts were full length ( 380 nucleotides; Fig. 5b, lane 11). Considering this difference in the transcript size /shorter transcripts contain less radioactivityl, the number of transcripts produced after a 5-min incubation at $0.3 \mathrm{M} \mathrm{KCl}$ was approximately the same as that produced at $50 \mathrm{~mm} \mathrm{KCl}$. This similarity in the number of initiated transcripts at early times of the transcription reaction also supports the notion that a single round of transcription was observed in these experiments. At both $\mathrm{KCl}$ concentrations, the addition of TGAla caused about an eightfold stimulation of transcription (cf. solid and open squares for $50 \mathrm{mM} \mathrm{KCl}$ or solid and open circles for $0.3 \mathrm{M} \mathrm{KCl}$ in Fig. $5 \mathrm{c}$ ). Thus, the degree of stimulation by TGAla was almost the same under single- and multiple-round transcription conditions. This indicates that TGAla stimulates transcription principally by increasing the number of preinitiation complexes rather than by increasing either the initiation frequency from a single preinitiation complex or the elongation rate.

\section{TGA1a-dependent preinitiation complexes remain committed during multiple-round transcription}

Relevant to the mechanism of action of TGAla, we then investigated whether the TGAla-dependent preinitiation complexes remain committed to the initial templates during multiple rounds of transcription. If so, this 


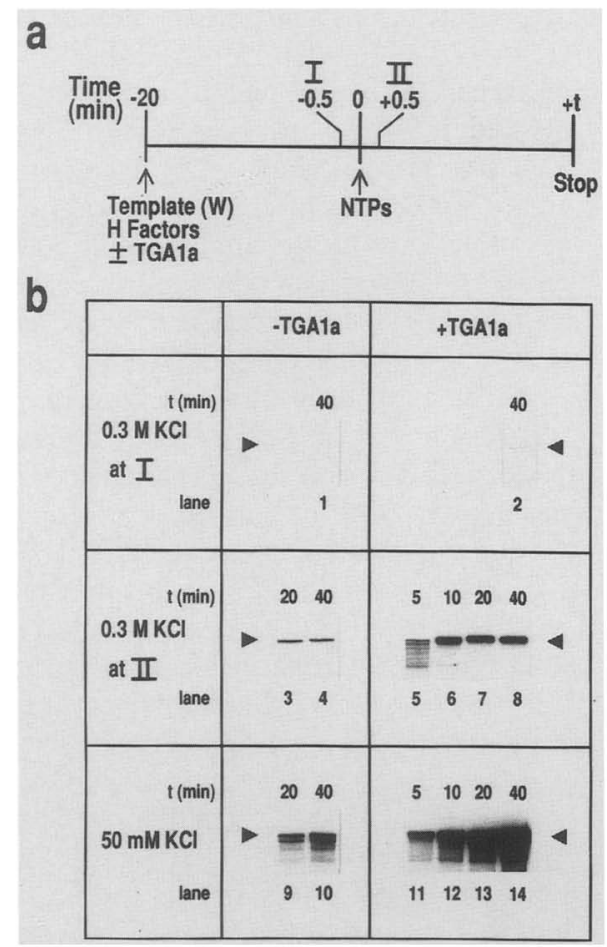

C

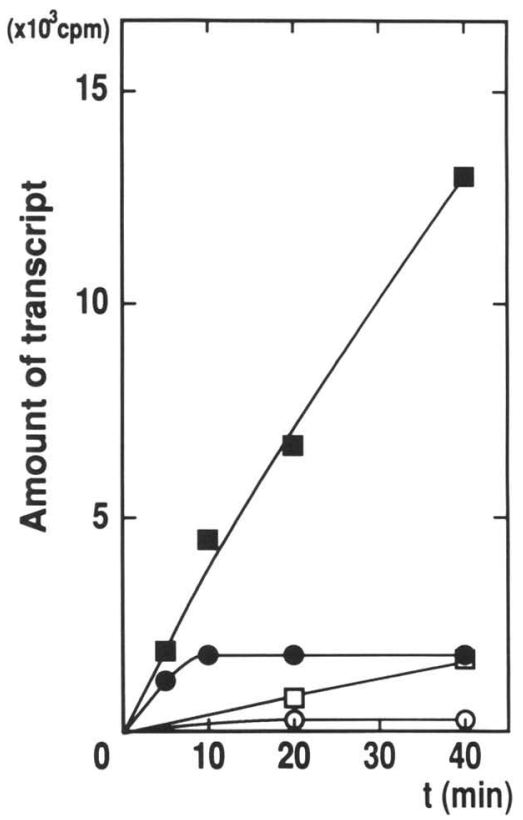

Figure 5. TGAla stimulates a single round of transcription in vitro. (a) The timetable for the experiments. (H Factors) HeLa general factors; (NTPs) ribonucleoside triphosphates. $(b)$ Transcription stimulation by TGAla is observed in both single- and multiple-round transcriptions. The transcription reaction was carried out with $(+; 100 \mathrm{ng} /$ assay) or without $|-|$ TGAla. The final concentrations of $\mathrm{KCl}$ and the times when the concentration was changed from $50 \mathrm{mM} \mathrm{KCl}$ (standard conditions) to $0.3 \mathrm{M} \mathrm{KCl}$ are indicated. (t) Incubation time as indicated in $a$. Arrowheads indicate the 380-nucleotide-specific transcript. (c) The transcripts shown in $b$ were quantified by measuring the amounts of radioactivity of the corresponding bands by a scintillation counter. The amount of radioactivity was used to represent the amount of transcription (O) $0.3 \mathrm{M} \mathrm{KCl}$ at II, $-\mathrm{TGAla}$; $(0.3 \mathrm{M} \mathrm{KCl}$ at II, $+\mathrm{TGAla}$; (口) $50 \mathrm{mM} \mathrm{KCl}$, -TGAla; ( $50 \mathrm{~mm} \mathrm{KCl,} \mathrm{+} \mathrm{TGAla.} \mathrm{Results} \mathrm{obtained} \mathrm{in} \mathrm{the} \mathrm{same} \mathrm{experiment} \mathrm{are} \mathrm{shown.}$

would raise the possibility that TGAla is required only transiently to stimulate transcription. For the study of template commitment of preinitiation complexes, it is desirable that the transcription system is capable of efficient reinitiation. As shown in Figure $5 \mathrm{c}$, the absolute level of transcripts at 40 min postinitiation was eightfold higher under multiple-round transcription conditions than under single-round transcription conditions in both the presence and the absence of TGAla (cf. solid square and circle, or open square and circle). This indicates that efficient reinitiation occurs under multiple-round transcription conditions (standard assay conditions). The occurrence of large amounts of discrete shorter transcripts under multiple-round transcription conditions (e.g., Fig. 5b, lane 14) also suggests efficient reinitiation, because these shorter transcripts are thought to represent the premature terminated products of latter rounds of transcription on the same G-free sequence template (Sawadogo and Roeder 1985a; Carcamo et al. 1989).

We first investigated the requirement of TGAla before and after initial preinitiation complex formation by addition either of an oligonucleotide (HW) that contains a TGAla-binding site or an oligonucleotide (HM) that does not bind TGAla (Fig. 6). Preinitiation complexes were formed, and the reaction was arrested at this stage by preincubation in the absence of NTPs. Transcription was initiated by the addition of NTPs, and the transcripts generated in $20 \mathrm{~min}$ were analyzed (see the timetable in Fig. 6). Lanes 1 and 2 show the level of transcript without and with transcription stimulation by TGAla, respectively. The addition of $200 \mathrm{ng}$ of $\mathrm{HW}$ per assay before the preincubation abolished the transcription stimulation by TGAla (lane 3), but the same amount of HM decreased the transcript only slightly (lane 4). In contrast, neither HW nor HM significantly affected the activation by TGAla when added after the preincubation (lanes 5 and 6; NTPs were added 5 min after the addition of the oligonucleotides). These results show that TGAla is required during the formation of preinitiation complex to stimulate transcription, as expected from the above-described action of TGAla in increasing the number of preinitiation complexes. They also raise the possibility that TGAla may not be needed in the subsequent steps, because the addition of $\mathrm{HW}$ after preinitiation complex formation did not significantly affect the overall level of transcription activation. However, we cannot exclude the possibility that TGAla may persist and/or be required after preinitiation complex formation because it could form a very tight complex /with the HeLa general factors) that becomes resistant to competition by HW. To assemble the HW-resistant complex, 

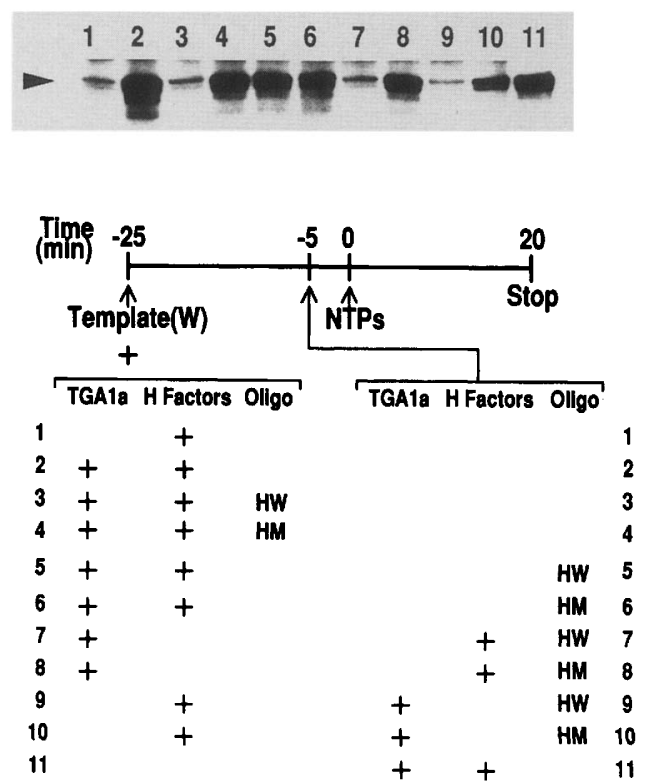

Figure 6. TGAla-dependent preinitiation complexes remain committed to templates. The timetable of the transcription reaction is shown below the autoradiogram. The program for each lane on the top is shown at the bottom. The program indicates the time point at which the indicated components were added to the reaction mixture. A total of $100 \mathrm{ng} /$ assay of TGAla was used. (HW) The oligonucleotide containing the wild-type hex-1 (200 ng/assay); (HM) the oligonucleotide containing the mutant hex-1 (200 ng/assay). The other abbreviations are the same as in Fig. 5. Arrowhead indicates the specific transcripts.

both TGAla and the HeLa general factors were needed during the preincubation. Omission of either component prevented the formation of the HW-resistant complex (lanes 7-10).

In addition to showing a requirement of TGAla during preinitiation complex formation, this experiment indicates that HW does not significantly affect the level of TGAla-dependent transcription, even under conditions of multiple rounds of transcription, once preinitiation complexes for the first round are formed. This suggests that some part of the preinitiation complex remains committed to the promoter site, even after transcription initiation, and that this complex is preferably used for the secondary initiations by RNA polymerase. For reasons stated above these experiments do not establish whether the template commitment during multiple round transcription occurs in the absence of TGAla.

\section{Discussion}

We have demonstrated that a plant transcription activator TGAla can function in a human in vitro transcription system. We have also shown that TGAla activates transcription by increasing the number of preinitiation complexes on the promoter. These results provide strong evidence that plants and animals share at least one common transcription activation mechanism.
The purified TGA1 a fraction contains three related polypeptides

We found that the purified fraction of TGAla contained three polypeptides with different translation start sites (Fig. 1b). The two shorter polypeptides probably result from use of two other methionine codons (Met-41 and Met-56) as translation start sites (Fig. 1d) in E. coli. All of the three polypeptides are likely to be active in DNA binding, because they were purified by two different DNA affinity chromatography steps. However, the fulllength TGAla (Fig. 1, band I) showed only weak binding activity in Southwestern blot analysis (Fig. 1c). This result could be explained if there is differential renaturation of the three polypeptides after denaturation by SDS. We found that after denaturation in guanidine hydrochloride, the renatured full-length TGAla barely recovered its binding activity. In contrast, a shorter derivative of TGAla (containing only the DNA-binding domain) readily recovered most of its binding activity (K. Seipel, unpubl.).

We do not know whether all three TGAla derivatives are equally active in transcription activation. Although the two shorter derivatives lack a portion of the acidic region that is presumably an activation domain, they retain the entire region of another putative activation domain, the glutamine-rich region (see below).

\section{Transcription activation mechanism of TGA1a}

Taking advantage of an in vitro transcription system, we demonstrated that TGAla increased the number of preinitiation complexes and that the TGAla-dependent preinitiation complexes remained committed to the templates under multiple-round transcription conditions. Figure 7 summarizes the activation mechanism of TGAla. When preinitiation complexes are formed with HeLa general factors ( $\mathrm{H}$ factors) on the template with the wild-type TGAla-binding site [Template (W)], the number of complexes is increased by TGAla. This step of activation is inhibited by oligonucleotide $\mathrm{HW}$, which contains the TGAla-binding site. It is not known whether TGAla remains associated with the preinitiation complexes or not. Transcription is initiated by the addition of ribonucleoside triphosphates (NTPs), and the preinitiation complex is changed into an elongation complex. This initiation step is inhibited by $0.3 \mathrm{M} \mathrm{KCl}$. For reinitiation of transcription, some part of the preinitiation complex that remains committed to the template after the first round of initiation is reused for the next round of initiation. This step circumvents the HW-sensitive step.

It is of interest to know which factors are involved in the part of the preinitiation complex that remains committed to the template and is reused for reinitiation of transcription. The absence of TGAla in this complex would indicate that TGAla is required only transiently to increase the number of initial preinitiation complexes and that the resulting preinitiation complexes can initiate transcription several times. In studies of the adenovirus major late promoter, preferential utilization of 


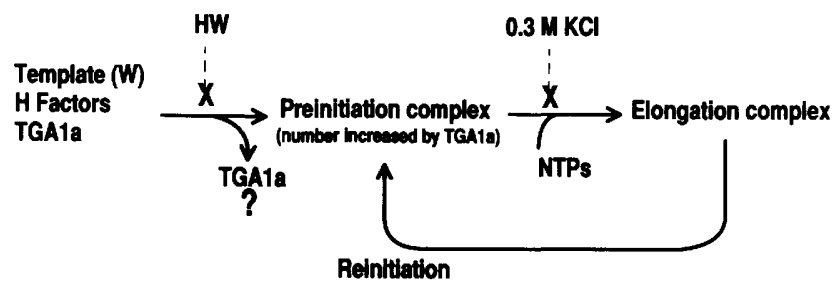

Figure 7. Transcription activation by TGAla. A proposed model showing the sequence of events in transcription initiation (Hawley and Roeder 1987) and the activation mechanism of TGAla. The oligonucleotide $\mathrm{HW}$ inhibits the increase in the number of the preinitiation complexes. The conversion of the preinitiation complex into the elongation complex is inhibited by $0.3 \mathrm{M} \mathrm{KCl}$. The reinitiation of transcription involves a complex that bypasses the HW-sensitive step. It has not been ascertained whether TGAla is released after formation of the preinitiation complex. Abbreviations are the same as in Fig. 5.

templates used in the first round of transcription was reported (Hawley and Roeder 1987); and when analyzed by footprinting assays in the presence of its sequencespecific activator upstream stimulating factor (USF), some complex minimally containing USF and TFIID was found to remain at the promoter site after initiation (Van Dyke et al. 1988). In our case, a similar complex including TGAla might remain at the promoter site, although this complex is resistant to HW. To address this question, it may be possible to isolate the template-associated complex, because of the apparent stability of the complex during several rounds of initiations, for further biochemical characterization. The idea that sequence-specific DNA-binding proteins might be needed for the establishment but not for the maintenance and continued utilization of active preinitiation complexes was also suggested from studies of adenovirus E4 promoter activation by ATF (Hai et al. 1988; Horikoshi et al. 1988b); this idea was best demonstrated for yeast $5 \mathrm{~S}$ and tRNA genes, which are transcribed by RNA polymerase III (Kassavetis et al. 1990).

\section{Transcription activation mechanisms in plants versus animals}

There has been some evidence that transcription activation mechanisms are conserved among unrelated eukaryotes because the yeast transcription activator GAL4 functions in various eukaryotes (Ptashne 1988), including plants (Ma et al. 1988). The work described here demonstrates for the first time that a plant transcription factor can function in an animal system. Because an in vivo transient expression system was used to examine the activity of GAL4 in plants, it was difficult to investigate the mechanisms by which the yeast factor stimulated transcription in plants. In contrast, using an in vitro system, we were able to demonstrate that the plant factor, TGAla, activates transcription by increasing the number of preinitiation complexes and that these remain active and committed during several rounds of transcription.

The transcription activation mechanism that enhances the preinitiation complex formation appears to be common among animal transcription activators examined so far, such as ATF (Hai et al. 1988; Horikoshi et al. 1988b), USF (Workman et al. 1990), and the progesterone receptor (Klein-Hitpass et al. 1990). Preinitiation complexes formed in the presence of TGAla were resistant to the oligonucleotide containing TGAla-binding site (Fig. 6). Similar stabilities of preinitiation complexes were observed with ATF (Hai et al. 1988), USF (also known as major late upstream transcription factor; Carcamo et al. 1989), and the progesterone receptor (KleinHitpass et al. 1990). Therefore, our demonstration that TGAla also acts in the same manner to stimulate transcription strengthens the notion that transcription activation mechanisms are conserved between plants and animals.

Although we have shown here that TGAla functions as a transcription activator, the protein domain responsible for this activation remains to be identified. We have proposed previously that an acidic region (amino acid residues $20-67$ ) and a relatively glutamine-rich region (amino acid residues 259-347) of TGAla may serve as activation domains (Katagiri et al. 1989) because such motifs are known to activate transcription in yeast and animals (Ptashne 1988; Mitchell and Tjian 1989). In the case of GAL4, an acidic region also functions as an activation domain in plants ( $\mathrm{Ma}$ et al. 1988). Further analyses of various deletion mutants of TGAla in the human in vitro transcription system will greatly facilitate functional dissection of this plant transcription factor.

\section{Materials and methods}

Plasmids and bacteria

The expression vector pET3a (Rosenberg et al. 1987) was used for the expression of TGAla. A double-stranded oligonucleotide shown below was first synthesized and cloned into the SacIKpnI site of pBluescript II KS + (Stratagene) to obtain pKE1. Unique restriction sites and important codons within the oligonucleotide region of pKE1 are indicated.

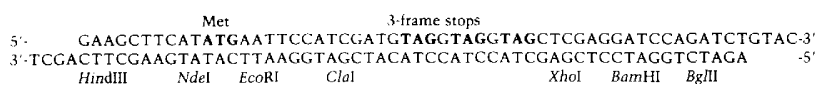

The 1.2-kb EcoRI-Xhol fragment of $\lambda$ hbl (Katagiri et al. 1989), which contains the entire TGAla-coding region except $2 \mathrm{bp}$ at the 5' end, was cloned into the EcoRI-XhoI site of pKE1 to obtain pKT1A. In this context, the methionine codon in the oligonucleotide region of $\mathrm{pKE}$ (shown above) became the first methionine codon of the TGAla reading frame. Sequence analysis of TGAla genomic clones revealed that the open reading frame starting from this methionine codon is identical to the authentic TGAla open reading frame (H. Fromm, unpubl.). The NdeI-BamHI fragment of pKTlA was cloned into the NdeIBamHI site of pET3a to obtain pKT7T1A. pKT7T1A was transformed into the host bacteria BL21(DE3)/plysS, and the transformant BL21(DE3)/plysS/pKT7T1A was used for the overproduction of TGAla.

The plasmids pUWDP and pUMDP containing the wild-type and mutant promoters, respectively (Yamazaki et al. 1990), were used as the DNA templates in the in vitro transcription assays. 


\section{Overproduction and purification of TGA1a}

BL21(DE3)/plysS/pKT7T1A was cultured in M9ZB medium at $37^{\circ} \mathrm{C}$ until the $A_{600}$ reached 0.4. IPTG was added to the culture to a final concentration of $0.4 \mathrm{~mm}$ and the bacteria were incubated at $37^{\circ} \mathrm{C}$ for $2 \mathrm{hr}$ before harvesting. The following procedure was performed at $4^{\circ} \mathrm{C}$. The bacteria (6 grams wet weight) were suspended in $80 \mathrm{ml}$ of buffer $\mathrm{E}$ [50 mM Tris- $\mathrm{HCl}$ ( $\mathrm{pH} 7.5], 1$ mM EDTA, $1 \mathrm{~mm}$ DTT, $1 \mathrm{~mm}$ phenylmethylsulfonyl fluoride], lysed by two cycles of freeze-thaw, and then extracted with $1 \mathrm{M}$ $\mathrm{NaCl}$. The crude extract was adjusted to $40 \%$ saturation of ammonium sulfate, and the precipitate was collected. The precipitate was suspended in buffer A-0.04 (buffer E plus $20 \%$ glycerol, $0.1 \%$ Nonidet P- $40,40 \mathrm{mM} \mathrm{KCl}$ ) and dialyzed against the same buffer. The fraction was applied onto a DE-52 (Whatman) column (bed volume $33 \mathrm{ml}$ ) equilibrated with buffer A-0.04 and the flowthrough fractions were pooled. The DE-52 fraction was then applied onto a P11 (Whatman) column (bed volume 5 ml) equilibrated with buffer A-0.04. After consecutive washings with buffer $\mathrm{A}-0.04$ and buffer $\mathrm{A}-0.2$ (same as A-0.04 except $0.2 \mathrm{M} \mathrm{KCl}$ ), the column was eluted with buffer A-0.5 (same as A-0.04 except $0.5 \mathrm{M} \mathrm{KCl}$ ), and the peak protein fractions were pooled. The P11 fraction was passed through two DNA affinity chromatography steps to remove a nonsperitic activity of transcription stimulation in the fraction, which was observed when analyzed in a wheat germ system /K. Yamazuki et al., unpubl.). The buffer of the fraction was exchanged to buffer B-0.2 [20 mM HEPES-KOH (pH 7.5), 1 mM EDTA, 10\% glycerol, $0.5 \mathrm{mM} \mathrm{DTT}, 0.2 \mathrm{M} \mathrm{KCl}]$ by gel filtration on Sephadex G-25 (Pharmacia), and one-third of the total fraction was applied onto the mutant DNA affinity column (bed volume $5 \mathrm{ml}$ ) equilibrated with the same buffer. The column was eluted with buffer B-0.4 (same as B-0.2, except $0.4 \mathrm{M} \mathrm{KCl}$ ) and the eluant was applied onto the wild-type DNA affinity column (bed volume $5 \mathrm{ml}$ ) equlibrated with buffer B-04. The column was eluted with buffer B-08 (same as B-02, except for $0.8 \mathrm{M} \mathrm{KCl}$ ), and the eluted fractions were pooled as the purified fraction of TGAla.

The DNA affinity columns were prepared essentially as described (Kadonaga and Tjian 1986), using HW and HM doublestranded oligonucleotides that contain the wild-type and mutant hex1 sequences, respectively. Concatemerized HW and $\mathrm{HM}$ were coupled to $\mathrm{CNBr}$-activated Sepharose $4 \mathrm{~B}$ (Pharmacia) to prepare the wild-type and mutant DNA affinity columns, respectively. hex1 is a cis-element $(-180$ to -160$)$ of the wheat histone H3 promoter (Mikami et al. 1987). It contains one copy of the TGACG motif that binds to TGAla (Katagiri et al. 1989). The nucleotide sequences of HW and HM are shown below.

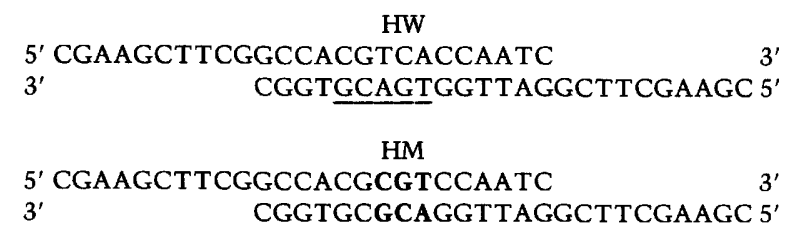

The TGACG motif of HW is underlined, and the mutations in HM are shown in bold letters. HW binds TGAla, whereas HM does not when analyzed as competitors in gel retardation assays (data not shown).

\section{In vitro transcription assays}

Partially purified fractions of RNA polymerase II, TFIIB, TFIID, and TFIIE/F were prepared as described (Horikoshi et al. 1988b). The activities of factors were RNA polymerase II, 0.7 units $/ \mu \mathrm{l}$; TFIIB, 0.85 units/ $\mu l$; TFIID, 1.5 units/ $\mu l$; and TFIIE/F, 0.7 units $/ \mu$ l. The reaction mixture ( $25 \mu \mathrm{l} /$ assay) contained $10 \mathrm{~mm}$ Tris- $\mathrm{HCl}(\mathrm{pH} 8.0), 40 \mathrm{~mm}$ HEPES-KOH $(\mathrm{pH} 7.9), 50 \mathrm{mM} \mathrm{KCl}, 2$ $\mathrm{mM} \mathrm{MgCl}_{2}, 10 \%$ glycerol, $1 \mathrm{mg} / \mathrm{ml}$ of BSA, $8 \mathrm{mM} \mathrm{DTT}, 100 \mu \mathrm{M}$ ATP, $100 \mu \mathrm{M}$ UTP, $20 \mu \mathrm{M}$ CTP, $5 \mu \mathrm{Ci}\left[\alpha^{-32} \mathrm{P}\right] \mathrm{CTP}(800 \mathrm{Ci} /$ mmole), $50 \mu \mathrm{M}$ 3'-O-methyl GTP, 0.15 unit of RNase Tl (Pharmacia), 0.8 unit of RNasin (Promega), $0.2 \mu \mathrm{g}$ of DNA template, $0.5 \mu l$ of TFIIB, $0.5 \mu l$ of TFIIE/F, $1 \mu$ l of TFIID, $0.25 \mu l$ of RNA polymerase II, and the indicated amount of TGAla. The standard incubation was at $30^{\circ} \mathrm{C}$ for $20 \mathrm{~min}$. After the incubation, the reaction was terminated by the addition of $75 \mu \mathrm{l}$ of stop solution $10.5 \%$ SDS, $10 \mathrm{mM}$ EDTA, $150 \mathrm{~mm}$ sodium acetate, 50 $\mu \mathrm{g} / \mathrm{ml}$ of tRNA). After extraction with phenol and chloroform, the transcripts were analyzed on a $6 \%$ sequencing gel. For the depleted HeLa general factors, the mixture of TFIIB, TFIID, TFIIE/F, and RNA polymerase II was preincubated with $10 \mathrm{ng} /$ assay of $\mathrm{HW}$ at $30^{\circ} \mathrm{C}$ for $30 \mathrm{~min}$ before the reaction. In experiments involving a preincubation step, nucleoside triphosphates and the indicated components were omitted from the preincubation mixture. The components indicated in the figures were added according to the timetables. The reactions were stopped, and the transcripts were analyzed as described above. Amounts of transcripts were measured by determining the radioactivity in excised gel bands using a scintillation counter.

\section{Primer extension assay}

In vitro transcription with (100 ng/assay) or without TGAla was carried out under standard assay conditions, except that $\left[\alpha^{-32} \mathrm{P}\right] \mathrm{CTP}$ was omitted from the reaction mixture. The transcripts were analyzed by primer extension as described (Hai et al. 1988), using an oligonucleotide primer complementary to +94 to +115 of the template, pUWDP. The amount of the primer used was in excess to that of the transcripts. For reference, pUWDP was sequenced with the same primer using a Sequenase sequencing kit (U.S. Biochemicals).

\section{Amino-terminal sequencing of protein}

The three polypeptides in the TGAla preparation were separated by SDS-PAGE, blotted onto polyvinylidene difluoride membrane (Matsudaira 1987), and sequenced by a gas-phase (Applied Biosystems Model 470A) or pulsed-liquid protein sequencer (Model 477A). Both sequencers were equipped with online PTH analyzers (Model 120A) and data analysis modules (Model 900A).

\section{Southwestern blot}

Southwestern blot analysis was performed essentially as described (Miskimins et al. 1985). A 112-bp fragment containing hex-1 (Katagiri et al. 1989) was labeled by Klenow fill-in and used as the binding probe. The binding mixture contained 5 $\mathrm{ng} / \mathrm{ml}$ of the probe $\left(7 \times 10^{5} \mathrm{cpm} / \mathrm{ml}\right)$ and $10 \mu \mathrm{g} / \mathrm{ml}$ of poly[d(IC). As a competitor, $18 \mathrm{ng} / \mathrm{ml}$ of either HW or HM was added to the binding mixture.

\section{Acknowledgments}

We thank Dr. F. William Studier for the T7 expression system, the Protein Sequencing Facility at The Rockefeller University (supported by BRSG S15 CA46157) for amino-terminal sequence determination of TGAla, Dr. Yoshiaki Ohkuma for helpful advice on the purification of TGAla, Drs. Philip N. Benfey and Alan Brunelle for critical reading of the manuscript, and Hugh Williams for photography. This work was supported by grants from Monsanto Co. to N.-H.C., from the Ministry of 
Education, Science, and Culture of Japan to K.Y., from the National Institutes of Health to R.G.R., and from Pew Trusts to the Rockefeller University. K.Y. was supported by a grant from the Suntory Company to The Rockefeller University. M.H. is an Alexandrine and Alexander L. Sinsheimer Scholar.

The publication costs of this article were defrayed in part by payment of page charges. This article must therefore be hereby marked "advertisement" in accordance with 18 USC section 1734 solely to indicate this fact.

\section{References}

Abmayr, S.M., J.L Workman, and R.G. Roeder. 1988. The pseudorabies immediate early protein stimulates in vitro transcription by facilitating TFIID : promoter interactions. Genes Dev. 2: 542-553.

An, G., P.R. Ebert, B.-Y. Yi, and C.-H. Choi. 1986. Both TATA box and upstream regions are required for the nopaline synthase promoter activity in transformed tobacco cells. Mol. Gen. Genet. 203: 245-250.

Benfey, P.N., L. Ren, and N.-H. Chua. 1989. The CaMV 35S enhancer contains at least two domains which can confer different developmental and tissue-specific expression patterns. EMBO I. 8: 2195-2202.

- 1990a. Tissue-specific expression from CaMV 35 S enhancer subdomains in early stages of plant development. EMBO /. 9: 1677-1684.

- 1990b. Combinatorial and synergistic properties of CaMV 35S enhancer subdomains. EMBO J. 9: 1685-1696.

Bouchez, D., J.G. Tokuhisa, D.J. Llewellyn, E.S. Dennis, and J.G. Ellis. 1989. The ocs-element is a component of the promoters of several T-DNA and plant viral genes. EMBO $J$. 8: 4197-4204.

Cai, H. and D.S. Luse. 1987. Transcription initiation by RNA polymerase II in vitro. J. Biol. Chem. 262: 298-304.

Carcamo, J., S. Lobos, A. Merino, L. Buckbinder, R. Weinmann, V. Natarajan, and D. Reinberg. 1989. Factors involved in specific transcription by mammalian RNA polymerase II. $J$. Biol. Chem. 264: 7704-7714.

Dignam, J.D., R.M. Lebovitz, and R.G. Roeder. 1983a. Accurate transcription initiation by RNA polymerase II in a soluble extract from isolated mammalian nuclei. Nucleic Acids Res. 11: $1475-1489$.

Dignam, J.D., P.L. Martin, B.S. Shastry, and R.G. Roeder. 1983b. Eukaryotic gene transcription with purified components. Methods Enzymol. 101: 582-598.

Ellis, J.G., D.J. Llewellyn, J.C. Walker, E.S. Dennis, and W.J. Peacock. 1987. The ocs element: A 16 base pair palindrome essential for activity of the octopine synthase enhancer. EMBO J. 6: 3203-3208.

Fischer, J.A., E. Giniger, T. Maniatis, and M. Ptashne. 1988. GAL4 activates transcription in Drosophila. Nature 332: 853-856.

Fromm, H., F. Katagiri, and N.-H. Chua. 1989. An octopine synthase enhancer element directs tissue-specific expression and binds ASF-1, a factor from tobacco nuclear extracts. Plant Cell 1: 977-984.

Guilley, H., R.K. Dudley, G. Jonard, E. Balàzs, and K.E. Richards. 1982. Transcription of cauliflower mosaic virus DNA: detection of promoter sequences, and characterization of transcripts. Cell 30: 763-773.

Hai, T., M. Horikoshi, R.G. Roeder, and M.R. Green. 1988. Analysis of the role of the transcription factor ATF in the assembly of a functional preinitiation complex. Cell 54: 1043-1051.

Hawley, D.K. and R.G. Roeder. 1985. Separation and partial characterization of three functional steps in transcription initiation by human RNA polymerase II. J. Biol. Chem. 260: $8163-8172$.

- 1987. Functional steps in transcription initiation and reinitiation from the major late promoter in a HeLa nuclear extract. I. Biol. Chem. 262: 3452-3461.

Horikoshi, M., M.F. Carey, H. Kakidani, and R.G. Roeder. 1988a. Mechanism of action of a yeast activator: Direct effect of GAL4 derivatives on mammalian TFIID-promoter interactions. Cell 54: 665-669.

Horikoshi, M., T. Hai, Y.-S. Lin, M.R. Green, and R.G. Roeder. 1988b. Transcription factor ATF interacts with the TATA factor to facilitate establishment of a preinitiation complex. Cell 54: 1033-1042.

Kadonaga, J.T. and R. Tjian. 1986. Affinity purification of sequence-specific DNA binding proteins. Proc. Natl. Acad. Sci. 83: 5889-5893.

Kakidani, H. and M. Ptashne. 1988. GAL4 activates gene expression in mammalian cells. Cell 52: 161-167.

Kassavetis, G.A., B.R. Braun, L.H. Nguyen, and E.P. Geiduschek. 1990. S. cerevisiae TFIIIB is the transcription initiation factor proper of RNA polymerase III, while TFIIIA and TFIIIC are assembly factors. Cell 60: 235-245.

Katagiri, F., E. Lam, and N.-H. Chua. 1989. Two tobacco DNAbinding proteins with homology to the nuclear factor CREB. Nature 340: 727-730.

Klein-Hitpass, L., S.Y. Tsai, N.L. Weigel, G.F. Allan, D. Riley, R. Rodriguez, W.T. Schrader, M.-J. Tsai, and B.W. O'Malley. 1990. The progesterone receptor stimulates cell-free transcription by enhancing the formation of a stable preinitiation complex. Cell 60: 247-257.

Lam, E., P.N. Benfey, P.M. Gilmartin, R.-X. Fang, and N.-H. Chua. 1989. Site-specific mutations alter in vitro factor binding and change promoter expression pattern in transgenic plants. Proc. Natl. Acad. Sci. 86: 7890-7894.

Lam, E., F. Katagiri, and N.-H. Chua. 1990. Plant nuclear factor ASF-1 binds to an essential region of the nopaline synthase promoter. J. Biol. Chem. 265: 9909-9913.

Ma, J., E. Przibilla, J. Hu, L. Bogorad, and M. Ptashne. 1988. Yeast activators stimulate plant gene expression. Nature 334: 631-633.

Matsudaira, P. 1987. Sequence from picomole quantities of proteins electroblotted onto polyvinylidene difluoride membranes. I. Biol. Chem. 262: 10035-10038.

Mikami, K., T. Tabata, T. Kawata, T. Nakayama, and M. Iwabuchi. 1987. Nuclear protein(s) binding to the conserved DNA hexameric sequence postulated to regulate transcription of wheat histone genes. FEBS Lett. 223: 273-278.

Mikami, K., H. Takase, T. Tabata, and M. Iwabuchi. 1989a. Multiplicity of the DNA-binding protein HBP-1 specific to the conserved hexameric sequence ACGTCA in various plant gene promoters. FEBS Lett. 256: 67-70.

Mikami, K., A. Sakamoto, H. Takase, T. Tabata, and M. Iwabuchi. 1989b. Wheat nuclear protein HBP-1 binds to the hexameric sequence in the promoter of various plant genes. Nucleic Acids Res. 17: 9707-9717.

Miskimins, W.K., M.P. Roberts, A. McClelland, and F.H. Ruddle. 1985. Use of a protein-blotting procedure and a specific DNA probe to identify nuclear proteins that recognize the promoter region of the transferrin receptor gene. Proc. Natl. Acad. Sci. 82: 6741-6744.

Mitchell, P.J. and R. Tiian. 1989. Transcriptional regulation in mammalian cells by sequence-specific DNA binding proteins. Science 245: 371-378.

Odell, J.T., F. Nagy, and N.-H. Chua. 1985. Identification of DNA sequences required for activity of the cauliflower mo- 
saic virus $35 \mathrm{~S}$ promoter. Nature 313: 810-812.

Pfeiffer, P. and T. Hohn. 1983. Involvement of reverse transcription in the replication of cauliflower mosaic virus: A detailed model and test of some aspects. Cell 33: 781-789.

Ptashne, M. 1988. How eukaryotic transcriptional activators work. Nature 335: 683-689.

Rosenberg, A.H., B.N. Lade, D. Chui, S. -W. Lin, J.J. Dunn, and F.W. Studier. 1987. Vectors for selective expression of cloned DNAs by T7 RNA polymerase. Gene 56: 125-135.

Saltzman, A.G. and R. Weinmann. 1989. Promoter specificity and modulation of RNA polymerase II transcription. FASEB J. 3: 1723-1733.

Sanders, P.R., J.A. Winter, A.R. Barnason, S.G. Rogers, and R.T. Fraley. 1987. Comparison of cauliflower mosaic virus 35S and nopaline synthase promoters in transgenic plants. $\mathrm{Nu}$ cleic Acids Res. 15: 1543-1558.

Sawadogo, M. and R.G. Roeder. 1985a. Interaction of a genespecific transcription factor with the adenovirus major late promoter upstream of the TATA box region. Cell 43: 165175.

- 1985b. Factors involved in specific transcription by human RNA polymerase II: Analysis by a rapid and quantitative in vitro assay. Proc. Natl. Acad. Sci. 82: 4394-4398.

Singh, K., J.G. Tokuhisa, E.S. Dennis, and W.J. Peacock. 1989. Saturation mutagenesis of the octopine synthase enhancer: Correlation of mutant phenotypes with binding of a nuclear protein factor. Proc. Natl. Acad. Sci. 86: 3733-3737.

Van Dyke, M.W., R.G. Roeder, and M. Sawadogo. 1988. Physical analysis of transcription preinitiation complex assembly on a class II gene promoter. Science 241: 13351338.

Webster, N., J.R. Jin, S. Green, M. Hollis, and P. Chambon. 1988. The yeast $\mathrm{UAS}_{\mathrm{G}}$ is a transcriptional enhancer in human HeLa cells in the presence of the GAL4 trans-activator. Cell 52: 169-178.

Workman, J.L., S.M. Abmayr, W.A. Cromlish, and R.G. Roeder. 1988. Transcriptional regulation by the immediate early protein of pseudorabies virus during in vitro nucleosome assembly. Cell 55: 211-219.

Workman, J.L., R.G. Roeder, and R.E. Kingston. 1990. An upstream transcription factor, USF (MLTF), facilitates the formation of preinitiation complexes during in vitro chromatin assembly. EMBO J. 9: 1299-1308.

Yamazaki, K., F. Katagiri, H. Imaseki, and N.-H. Chua. 1990. TGAla, a tobacco DNA-binding protein increases the rate of initiation in a plant in vitro transcription system. Proc. Natl. Acad. Sci. 87: 7035-7039. 


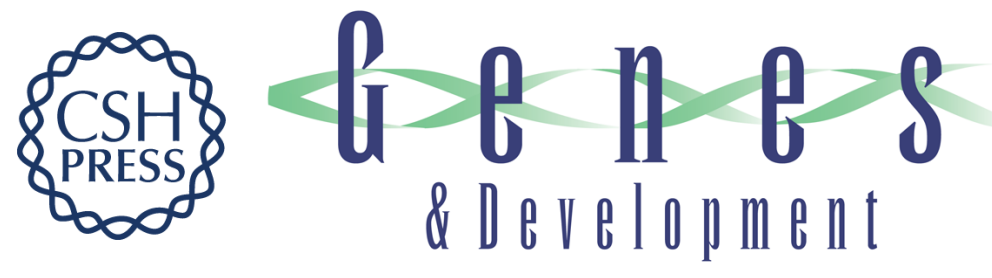

\section{A plant DNA-binding protein increases the number of active preinitiation complexes in a human in vitro transcription system.}

F Katagiri, K Yamazaki, M Horikoshi, et al.

Genes Dev. 1990, 4:

Access the most recent version at doi:10.1101/gad.4.11.1899

References This article cites 47 articles, 16 of which can be accessed free at:

http://genesdev.cshlp.org/content/4/11/1899.full.html\#ref-list-1

License

Email Alerting

Service

Receive free email alerts when new articles cite this article - sign up in the box at the top right corner of the article or click here.

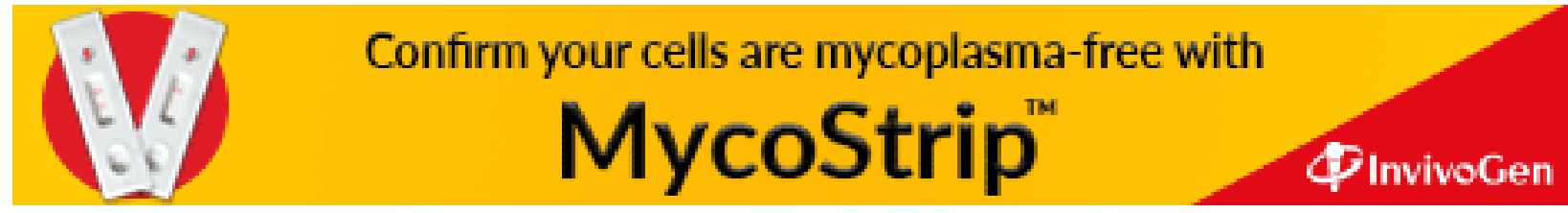

